\title{
Noise Mitigation and Related Factors of High Speed Railways
}

\author{
Inara Watson ${ }^{1}$, Amer $\mathrm{Ali}^{2}$, Ali Bayyati ${ }^{3}$
}

\begin{abstract}
The continuing rise of population and globalisation have a large impact on the transport system. Railway transport, particularly High-Speed Railways (HSR) offers many advantages compared with other modes of transportation. HSR can reduce the amount of pollution from transport and ease congestion on roads and at airports. High speed railways may mean more noise and vibration which reduce the quality of life, disturb sleep and negatively affect health in addition to other impacts on the wild life and nature in general. Therefore, it is very important for the development of HSR systems to consider effective measures to reduce the level of noise and vibration among its most important goals. This paper reports on a research that takes the form of an investigation and critical evaluation of the key existing factors that contribute to noise emissions from HSR and discusses possible ways to reduce them. A comparison of different influential factors and mitigation measures concerning a selected HSR systems will be reported. From the evidence that has been gathered from different sources and related critical evaluations, conclusions can be made to show that in some cases the increases in speed would not only be a threat to the environmental sustainability but also affect the economical sustainability of HSR systems. Most of the findings are based on research by the authors and data gathered from relevant sources including in depth research concerning HSR systems in selected countries, available railway statistics and relevant European and Institutional Publications. The expected outcomes of this research will contribute to the development and advances of more sustainable HSR systems that can meet the growing demand for travel due to the continuing growth in world population and globalization.
\end{abstract}

Keywords: High-speed rail, noise mitigation, environment, sustainability.

\section{Introduction}

Transport systems provide access and mobility for society and support an increase in economic growth. However, the environmental and social costs of transport increases. Very often the most obvious form of pollution from transport is noise. The noise level is continually increasing, and the majority of these increases have been drawn by the increasing amount of transport on roads and expansion of airports. Noise reduces the quality of life, disturbs sleep, negatively affects health and reduces property prices. It was estimated that in the EU around 40 per cent of the population are exposed to road traffic noise of $55 \mathrm{~dB}(\mathrm{~A})$, and 20 per cent are exposed to levels exceeding $65 \mathrm{~dB}(\mathrm{~A})$, which is defined as an unacceptable level of noise (Whitelegg and Haq, 2003). Road traffic accounts for $64 \%$ of total noise levels, rail traffic $10 \%$ and air traffic $26 \%$ (Efficient Transport for Europe, 1998). The number of people affected by rail noise is substantially less than the number of people affected by road noise. Noise is one of the $\mid{ }^{1} \mathrm{PhD}$ Student at London South Bank University

$\left.\right|^{2}(B S c(E n g)$, MSc, PhD, CEng, FICE, FCIHT, FIHE, MASCE, MSEI, MT\&DI, SFHE), Specialised in highway and transportation engineering.

$\mid{ }^{3}$ London South Bank University. 
most important environmental emissions for people who are living next to railway lines. Noise and vibration generated by trains increase with the increase in speed. The basic unit used to measure sound or noise is the Decibel or $\mathrm{dB}(\mathrm{A})$. People are more sensitive at higher frequencies than to lower frequencies (Wolf, 2010). The biggest concern about HSR is the amount of noise produced by trains and the number of people who may be affected by it. Until recently, the most popular method to reduce noise was to use noise barriers and to insulate windows.

\section{Factors Affecting Noise Level}

The noise generated by HSR can be less than the noise from a conventional line with mixed traffic. Many different factors can affect the noise level; it can be the age of the infrastructure and materials that have been used to build the track, level of maintenance, rolling stock and the way in which the railway is operated. If a railway track is in a poor state and has a low level of maintenance then it would emit $10 \mathrm{~dB}(\mathrm{~A})$ more than a new one (Transport Policy and the Environment, 1990). Table 1 shows that there is a strong relationship between noise level and speed. Also, there is a strong relationship between noise level and distance to the receiver and between noise level and infrastructure type. The noise level was influenced more by the distance than by changes in speed. To reduce the noise level propagation, it is more effective to put the railway line in cuttings, but such a solution can be expensive.

Table 1. Maximum and realised noise emissions of existing high-speed trains (Source: Clausen et.al, 2012; Feilden, Wickens and Yates,1995)

\begin{tabular}{|c|c|c|c|}
\hline $\begin{array}{c}\text { Speed in } \\
\mathbf{k m} / \mathbf{h}\end{array}$ & $\begin{array}{c}\text { Maximum noise emission } \\
\text { according TSI NOISE in } \mathbf{d B}(\mathbf{A})\end{array}$ & $\begin{array}{c}\text { Current emission of } \\
\text { German HS Trains in dB(A) }\end{array}$ & $\begin{array}{c}\text { Difference in } \\
\mathbf{d B}(\mathbf{A})\end{array}$ \\
\hline 200 & & $>80$ & \\
\hline 250 & 87 & $87-94$ & $0-7$ \\
\hline 300 & 91 & $91-95$ & $0-4$ \\
\hline 320 & 92 & $92-96$ & $0-4$ \\
\hline
\end{tabular}

TSI NOISE- European Railway Technical Specification for Interoperability for Noise, defines the maximum noise levels for Rolling Stock (RS). For high speed trains, the noise level emission is a big concern. For the German ICE with a speed of $200 \mathrm{~km} / \mathrm{h}$, at 25 metres from the track it was recorded that the noise level was over $80 \mathrm{~dB}(\mathrm{~A})$, and at a speed of $300 \mathrm{~km} / \mathrm{h}$ the noise level was around $90 \mathrm{~dB}(\mathrm{~A})$ (Feilden, Wickens, and Yates,1995). This is a major problem for numerous countries, where the railway tracks pass densely-populated areas. Doubling the speed will approximately increase the aerodynamic noise level by $18 \mathrm{~dB}(\mathrm{La})$.

Many different elements contribute to the total noise emission from trains including pantograph noise, aerodynamic noise generated by the car bodies, running noise generated from the underbody and noise from concrete structures. Pantograph noise consists of aerodynamic noise generated at the pantograph and pantograph shield, friction noise is caused by the collector running on the catenary and sparking noise between the collector and catenary. Aerodynamic noise generated by the air flow over 
the carriage is only relevant to high-speed trains (Martens et.al, 2018).

To reduce the negative impact of pantograph noise, bus cables were installed between pantographs to reduce sparking noise. Even if one pantograph bounces off the catenary, current still flows through the other pantograph, preventing sparks. Reducing the noise from the car body can be achieved with smoother surfaces of cars.

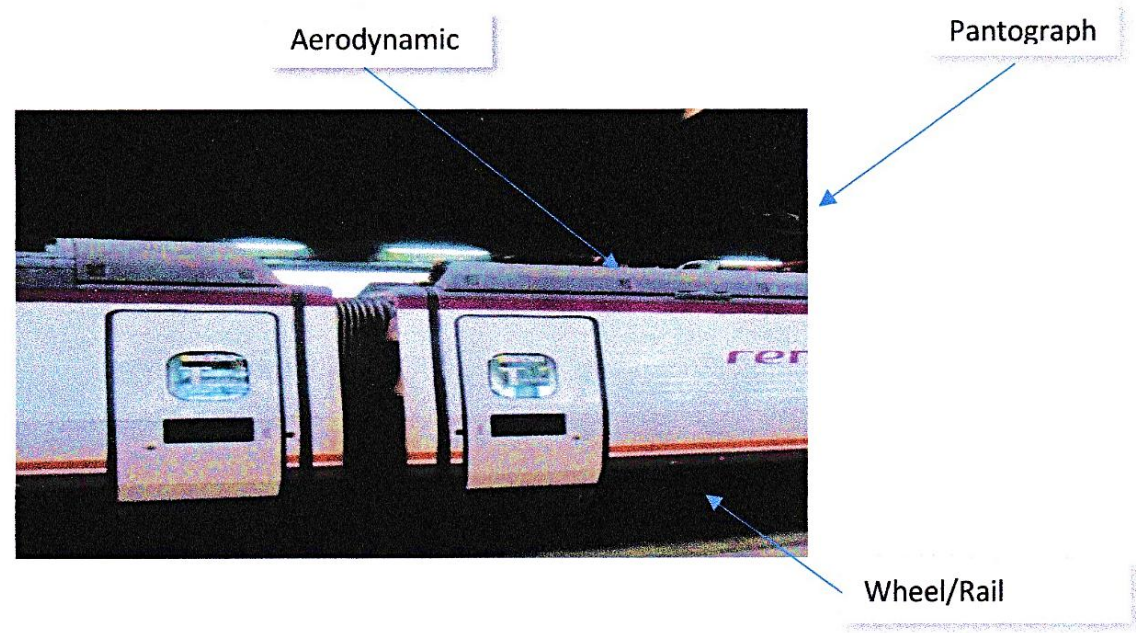

Figure 1. Major exterior noise sources on high-speed trains

Figure 1 shows the major exterior noise sources on high-speed trains which are: aerodynamic, pantograph and wheel-rail interaction noises. These noise sources are speed dependent. Traction noise, which is generated by the electric traction system, is distributed between the bogie height and the roof of the train. Noise from the cooling system will be the dominant traction noise (Zhang, and Jonasson, 2006). The level of traction noise varies for different types of locomotive or EMU and for different operational conditions. Noise from wheel-rail interactions is dependent on the wheel and rail roughness and on the speed of train. This type of noise can be partially mitigated by rail grinding. Aerodynamic noise becomes more important for HSR trains than the rolling noise (Zhang, 2010). It consists of noise generated from the pantograph, noise of the train, roughness of the RS body and gaps between cars, etc. Intensity of aerodynamic noise pollution depends on train speed.

Modern HSRS (High Speed Rolling Stock) has metal panels on top of the coaches to improve aerodynamic profile of coaches and pantograph. The pantograph is important as it is not sheltered by noise barriers. Moreover, the number of pantographs needed to collect the current for the train set could be reduced, and as a result, this would reduce the aerodynamic noise sources. This type of noise is insignificant for low and medium speed $(\mathrm{V}<200 \mathrm{~km} / \mathrm{h})$, important for high speed $(200<\mathrm{V}<300 \mathrm{~km} / \mathrm{h})$ and dominant for very high speed $(\mathrm{V}>300 \mathrm{~km} / \mathrm{h})$. Mechanical noise is dominant at low speed, wheel-rail interaction noise is dominant at speed up to $300 \mathrm{~km} / \mathrm{h}$ whilst the aerodynamic noise is dominant at speeds of over $300 \mathrm{~km} / \mathrm{h}$ (Giesler, 2011). The modern HSRS in the majority 
has a distributed power system which reduces noise emissions. However, a distributed power system increases the noise level inside the coaches. People inside the train are affected by different types of noise; traction noise, rolling and aerodynamic noises.

Table 2. HSRS in selected countries (Source: Adapted from Uic.org, 2018)

\begin{tabular}{|c|c|c|c|c|}
\hline Country & $\begin{array}{l}\text { Owners or } \\
\text { Operators }\end{array}$ & Class & Train set Formula & $\begin{array}{l}\text { Type of } \\
\text { power }\end{array}$ \\
\hline France, Belgium, UK & Eurostar & $\begin{array}{c}373 \text { e300 TGV- } \\
\text { TSMT }\end{array}$ & $\begin{array}{l}2 \text { Locomotives } \\
18 \text { Trailer Coaches }\end{array}$ & Concentrated \\
\hline $\begin{array}{l}\text { France, Belgium, } \\
\text { Netherlands }\end{array}$ & Thalys & $\begin{array}{l}\text { Thalys } \\
\text { PBKA }\end{array}$ & $\begin{array}{l}\text { 2 Locomotives } \\
\text { 8Trailer Coaches }\end{array}$ & Concentrated \\
\hline Germany & DB AG & 401(ICE1) & $\begin{array}{l}2 \text { Locomotives } \\
12 \text { Trailer Coaches }\end{array}$ & Concentrated \\
\hline Germany & DB AG & 403(ICE3) & $\begin{array}{l}4 \text { Motor Coaches } \\
4 \text { Trailer Coaches }\end{array}$ & Distributed \\
\hline Italy & Trenitalia & ETR460 & $\begin{array}{l}6 \text { Motor Coaches } \\
3 \text { Trailer Coaches }\end{array}$ & Distributed \\
\hline Italy & Trenitalia & ETR500 & $\begin{array}{l}2 \text { Locomotives } \\
12 \text { Trailer Coaches }\end{array}$ & Concentrated \\
\hline Spain & Renfe & S102 & $\begin{array}{c}2 \text { Locomotives } \\
12 \text { Trailer Coaches }\end{array}$ & Concentrated \\
\hline Spain & Renfe & S103 & $\begin{array}{l}4 \text { Motor Coaches } \\
4 \text { Trailer Coaches }\end{array}$ & Distributed \\
\hline China & CR & CRH1A & $\begin{array}{l}5 \text { Motor Coaches } \\
3 \text { Trailer Coaches }\end{array}$ & Distributed \\
\hline China & CR & CRH2G & $\begin{array}{l}4 \text { Motor Coaches } \\
4 \text { Trailer Coaches }\end{array}$ & Distributed \\
\hline Japan & JRW & $500-7000$ & 8 Motor Coaches & Distributed \\
\hline Turkey & TCDD & HT65000 & $\begin{array}{l}4 \text { Motor Coaches } \\
2 \text { Trailer Coaches }\end{array}$ & Distributed \\
\hline USA & Amtrak & Acela & $\begin{array}{l}2 \text { Locomotives } \\
6 \text { Trailer Coaches }\end{array}$ & Concentrated \\
\hline
\end{tabular}

Table 2 shows the type of power of HSRS in selected countries. With increasing the speed, the noise inside the train cars increases (Soeta and Shimokura, 2013). For HSR the noise from the bogie area has the larger impact on interior noise than aerodynamic noise. It is important to reduce the noise level inside passenger coaches for Electro-MultipleUnit (EMU) with distributed power components as traction motors are located beneath the passenger saloon. The floor of passenger carriages must be sound proofed (Zhang et.al,2016). Passenger cars must be designed to reduce noise inside the passenger saloon by using advanced materials and suitable design. Equipping the car bodies with shielding and acoustical absorption can provide cost-effective noise reduction. Countries such as Japan, China, and Turkey have only HSRs with a distributed traction system, but the USA uses rolling stock for their HSR with a concentrated traction system. Countries in Europe, such as Italy, France, Spain, Germany and UK have rolling stock for HSRs with both types of traction systems; distributed and concentrated. 
A significant contribution to noise level is the interaction between wheels and rails. Rolling noise occurs during the rolling movement of the wheel. The roughness of the wheel and rail generate the rolling noise when the wheel travels along the rail, but it also depends on the load and speed of the train. Articulated trains have less effect of running noise on passengers (Japanese railway technology today, 2001). Wheel and rail rolling noise is proportional to the third power of train speed (Lynch, 1998). To reduce this negative impact of running noise, different types of wheels were developed: solid wheels, resilient wheels and wheels provided with constrained layers. The most common is the solid wheel, which is used for high speed trains. It consists of a single steel part, but sometimes layers of viscoelastic material are placed between the web and a stiff constraining plate to reduce the wheel noise emission (Scott, 2009). The railway insulation pads which are placed between the rail and sleepers can sufficiently reduce the noise level radiated by the track.

The type of track, and the surface of the rail can make a difference by more than $+/-10$ $\mathrm{dB}(\mathrm{A})$. Also, buildings and civil engineering works can affect noise levels, or amplify or attenuate such levels (Feilden, 1995). There are measures to mitigate the rail-wheel noise including rail lubrication, grinding, noise barriers, damping etc. The most-cost efficient one is the reduction of roughness of rail by rail lubrication and grinding (Tuler and Kaewunruen, 2017). To reduce the noise level from the contact between the wheels and rail, wheel-track absorbers also can be used. This potentially reduces noise level by 1-3 $\mathrm{dB}(\mathrm{A})$ (Oertli, and Hubner, 2010). Mitigation of wheel noise is a difficult task as wheels interact not only with the rail but also with the substructure.

Today HSR often use ballastless tracks such as concrete slab-track. This type of rail support is not good for reducing noise and vibration emission (Sheng, Zhong and Li, 2017). Concrete structure noise is proportional to the second power of train speed. Embedding a viscoelastic material can reduce the level of noise emission from ballastless track. To reduce the noise level from the concrete, grooved slab mats can be placed in the general area of the rail (Japanese Railway Technology Today, 2001).

\section{Measures of Reduction in Noise Level}

There are three ways to reduce noise: at the source, which is the most effective way, around the noise source and at the receiver end. The decision-making process concerning the layout of railways is the most efficient stage for the reduction of noise and vibration. A straight track is the lowest noise generator, whilst curving slab track is the noisiest. Railways with sharp curves have a significant problem of wheel squeal. The corrugated track depending on brake type, can increase the noise level between $10 \mathrm{~dB}(\mathrm{~A})$ and $20 \mathrm{~dB}(\mathrm{~A})$ (The Railways, 1995). Elevated rails along the top of embankments, bridges and viaducts propagate noise over long distances and result in noise levels at a range of $75 \div 105 \mathrm{~dB}(\mathrm{~A})$. Furthermore, stiff embankments can be a source of high frequency vibration (Connolly et.al, 2014).

Different techniques for reducing noise at the source have been developed such as improving the infrastructure and rolling stock design, traffic management, using preventative maintenance, acoustical rail grinding, rail dampers, etc. Increasing the operational restrictions such as reducing the train weight, putting a limit on speed, 
operational time and reducing the number of trains using the line will reduce the level of noise.

There are various measures to control noise along the railway line which includes: noise barriers of various heights. Noise barriers can reduce the noise level between 5 and 15 $\mathrm{dB}(\mathrm{A})$ (Oertli, and Hubner, 2010). Usually for railways 2-metre-high noise barriers are used, but for HSR it needs to be 4 meters or more, as a high proportion of noise come from pantographs (Transport Policy and the Environment, 1990). The height of trains (Table 3) varies from $3.36 \mathrm{~m}$ for S102 type train to $4.32 \mathrm{~m}$ for Acela train. The width and height of trains influence the aerodynamic performance of running trains. Also, a coach length and inter coach connection can sufficiently affect the noise level.

In some cases, the noise barrier looks as if a box is completely covering the rail which sounds like a train running in a tunnel. This noise barrier sometimes has a partial or fully covered top. The barrier internally is covered with absorbent material. Pantographs are especially important because they are located on the roof of trains and not so much sheltered by noise barriers (Iglesias, Thompson, and Smith, 2017). In some cases, due to the topography nature of the area where a railway line is passing it can be necessary to use cuttings and tunnels. Also, it can be used to mitigate the noise level. However, this is a more expensive measure than using conventional noise barriers. Railways have a long tradition of tunnels as many HSR lines were constructed in long tunnels. The $327 \mathrm{~km}$ Hanover-Wurzburg line in Germany includes 62 tunnels totalling 118km (Transport Policy and the Environment, 1990). Tunnels can reduce noise level, but they can also generate noise. Entering a tunnel of a high-speed train generates the sonic boom effect and on top of this more noise emission will be produced from the ventilation shafts.

It would be more effective to minimise noise level from railway tracks by keeping the level of rails as low as possible as the ground and vegetation attenuate the occurring sounds. However, with changing climate and increasing extreme weather events there is a need to consider future possibilities of flooding for which the elevation of rails on top of embankment can become a necessity.

Measures to reduce the noise level inside a building are double or triple glazing and acoustic insulation. It is important to provide measures to reduce noise level in buildings at the design stage. Every doubling in distance from the HSR to the recipient will reduce the noise by approximately 3 to $4.5 \mathrm{~dB}(\mathrm{~A})$ which depends on the ground condition i.e. soft ground with vegetation or hard surface covered by concrete or asphalt (Wolf, 2010). Insulation inside the building can reduce the noise between 5 to $30 \mathrm{~dB}(\mathrm{~A})$ Jehanno, 2011). The most significant and sustainable lowering of the noise level can be achieved by a combination of RS and infrastructure related measures which will facilitate reducing the needs of noise barriers.

The railway stations and surrounding areas also exposed to higher noise level. Train dynamics, acceleration and deceleration, speed changes of through trains, etc. have considerable impact on the resultant noise level (Džambas, Lakušić, and Dragčević, 2018). In order to reduce the noise levels, absorbent material can be used to cover station furniture, trackside walkways and walls. 
Table 3. Comparison of selected HSRS, their maximum operational speed, noise values and density of population (Source: Poisson, Gautier, and Letourneaux, n.d.; Uic.org, 2018; Worldometers.info, 2018)

\begin{tabular}{|l|c|c|c|c|c|c|c|}
\hline Country & $\begin{array}{c}\text { Class of } \\
\text { Train }\end{array}$ & $\begin{array}{c}\text { Maximum } \\
\text { Operational } \\
\text { Speed in } \\
\mathrm{km} / \mathrm{h}\end{array}$ & $\begin{array}{c}\text { Maximum } \\
\text { Axle Load } \\
\text { in ton }\end{array}$ & $\begin{array}{c}\text { Train } \\
\text { Width, } \\
\text { in mm }\end{array}$ & $\begin{array}{c}\text { Train } \\
\text { Length, } \\
\text { in m }\end{array}$ & $\begin{array}{c}\text { Pass-by } \\
\text { Noise } \\
\text { Values } \\
\text { in dB(A) }\end{array}$ & $\begin{array}{c}\text { Density of } \\
\text { Population } \\
\text { by Country } \\
\text { in P/km }\end{array}$ \\
\hline $\begin{array}{l}\text { France, } \\
\text { Belgium, UK }\end{array}$ & $\begin{array}{c}373 \text { e300 } \\
\text { TGV-TSMT }\end{array}$ & 300 & 17 & 2814 & 394 & $\begin{array}{l}119 \\
380 \\
275\end{array}$ \\
\hline $\begin{array}{l}\text { France, } \\
\text { Belgium, } \\
\text { Netherlands }\end{array}$ & $\begin{array}{c}\text { Thalys } \\
\text { PBKA }\end{array}$ & 300 & 17 & 2904 & 200 & $90-92$ & 119 \\
\hline Germany & $401(\mathrm{ICE} 1)$ & 280 & 19.5 & 3020 & 358 & & 507 \\
\hline Germany & $403(\mathrm{ICE} 3)$ & 300 & 16 & 2950 & 200 & 89 & 236 \\
\hline Italy & ETR460 & 250 & 13.5 & 2800 & 237 & & 202 \\
\hline Italy & ETR500 & 300 & 17 & 2860 & 354 & 90.5 & 202 \\
\hline Spain & S102 & 300 & 17 & 2960 & 200,244 & & 93 \\
\hline Spain & S103 & 300 & $<17$ & 2950 & 200 & & 93 \\
\hline China & CRH1A & 200 & 16.5 & 3328 & 213,5 & & 151 \\
\hline China & CRH2G & 250 & 15.45 & 3380 & 201,4 & & 151 \\
\hline Japan & $500-7000$ & 285 & N/A & 3380 & 204 & & 349 \\
\hline Turkey & HT65000 & 250 & N/A & 2920 & 158,5 & & 106 \\
\hline USA & Acela & 241 & 23 & 3175 & 203 & & 36 \\
\hline TSI Limits & & 300 & & & & 91 & \\
\hline
\end{tabular}

Table 3 shows some characteristics of selected HSRS, noise values and density of population in selected countries. With the increasing wealth society getting less tolerant to noise pollution and mitigation measures getting more expensive. The majority of people affected by railway noise live in Western and Central Europe, primarily in Germany, Italy, Switzerland, France and Belgium. Approximately 60\% of the population affected by noise are in Germany and France and the highest level recorded was along the south-north corridor Genoa-Rotterdam (Vos, 2016). Railways around the world spent a substantial amount of financial resources to reduce or mitigate noise pollution from railways. One of the long-term goals of the German DB Railway is to cut noise emissions by half by 2020. The total cost of this will be $€ 2.3$ billion including noise barriers and double-glazed widows. France will invest $€ 193$ million in noise barriers and rail dampers (Clausen et.al, 2012). The cost of noise varies between 0.1 and 0.5 per cent of Europe's GDP (Banister, 2000). Approximately $€ 150-200$ million will be spent in Europe annually on noise barriers and window insulation (Oertli and Hubner, 2010). Increased cost of noise pollution can sufficiently affect economic sustainability of HSR.

\section{Conclusions}

Encouraging people to use the railway transport systems will improve air quality, reduce the noise level, deliver safety benefits and improve the quality of life. However, 
increasing traffic volumes and urbanisation increase noise pollution. National governments are required to implement policies and legislations, which should lead to a reduction in noise levels. Further increases in train speed, wagon loading, and traffic intensity will inevitably increase noise levels. Around 30\% of population in Europe are exposed to road noise. Currently most HSR services do not run during the night time when people are most sensitive to noise emissions, but in the future, this may change and lead to an increase in HSR traffic as a result of the continuing rise in demand for daily travel including night time services.

Reducing the level of noise can be done through targeted investments, using new quieter technologies and developing new noise absorbing materials, reducing noise through regular maintenance of infrastructure and RS and through law enforcement concerning noisier trains. Improved designs of rolling stock can reduce the amount of noise pollution from the engine, air-conditioning and ventilation systems. Reducing noise from $72 \mathrm{~dB}(\mathrm{~A})$ to $52 \mathrm{~dB}(\mathrm{~A})$ in an average daily noise level will produce an annual saving of about $€ 158$ per person (Micheli, Farne, 2016). The future development of HSR transportation systems must consider railway noise emission reduction as one of the most important goals for developing sustainable HSR systems.

\section{References}

Banister, D. (2000). European transport policy and sustainable mobility. London: Spon Press, p.78.

Clausen, U., Doll, C., Franklin, F., Franklin, G., Heinrichmeyer, H., Kochsier, J., Rothengatter, W. and Sieber, N. (2012). Reducing Railway Noise Pollution. [online] Europarl.europa.eu. Available at: http://www.europarl.europa.eu/RegData/etudes/etudes/join/2012/474533/IPOLTRAN_ET(2012)474533_EN.pdf [Accessed 30 Apr. 2018].

Connolly, D., Kouroussis, G., Woodward, P., Alves Costa, P., Verlinden, O. and Forde, M. (2014). Field testing and analysis of bigh speed rail vibrations. [online] Available at: (https://www.sciencedirect.com/science/article/pii/S0267726114001857 [Accessed 30 Apr. 2018].

Džambas, T., Lakušić, S. and Dragčević, V. (2018). Traffic noise analysis in railway station zones. Applied Acoustics, [online] 137, pp.27-32. Available at: https://www.sciencedirect.com/science/article/pii/S0003682X17310964 [Accessed 1 May 2018].

Efficient Transport for Europe, (1998). Paris: OECD Publishing and European Conference of Ministers of Transport, p.25.

Feilden, G., Wickens, A. and Yates, I. (1995). Passenger transport after 2000 AD. London: Published by E \& FN Spon for the Royal Society, p.p.76.

Feilden, G., Wickens, A. and Yates, I. (1995). Passenger transport after 2000 AD. London: Published by E \& FN Spon for the Royal Society, p.p.76.

Giesler, N. (2011). HS2 London to the West Midlands Appraisal of Sustainability. [online] Gov.uk. Available at: https://www.gov.uk/government/uploads/system/uploads/attachment_data/file/370568/HS2_ London_to_the_West_Midlands-_sustainability_appraisal.pdf [Accessed 30 Apr. 2018].

Iglesias, E., Thompson, D. and Smith, M. (2017). Component-based model to predict aerodynamic noise from high-speed train pantographs. Journal of Sound and Vibration, [online] 394, pp.280-305. Available at: https://www.sciencedirect.com/science/article/pii/S0022460X17300512 [Accessed 1 May 2015].

Japanese railway technology today. (2001). Tokyo: The Foundation, pp.21,90.

Jehanno, A. (2011). High Speed Rail and Sustainable Mobility. [ebook] Paris: UIC. Available at: http://www.apta.com/mc/hsr/previous/2011/presentations/Presentations/High-Speed-Rail-andSustainable-Mobility-A-Focus-on-Environmental-and-Social-Issues.pdf [Accessed 30 Apr. 2018].

Lynch, T. (1998). High speed rail in the US. Amsterdam: Gordon \& Breach, p.83. 
Martens, A., Wedemann, J., Meunier, N. and Leclere, A. (2018). High speed train noise - sound source localization at fast passing trains. [online] Available at: http://webistem.com/acoustics2008/acoustics2008/cd1 /data/fa2002-sevilla/forumacusticum/archivos/noi03007.pdf [Accessed 30 Apr. 2018].

Micheli, G. and Farné, S. (2016). Urban railway traffic noise: Looking for the minimum cost for the whole community. Applied Acoustics, [online] 113, pp.121-131. Available at: https://www.sciencedirect.com/science/article/pii/S0003682X1630175X [Accessed 1 May 2018].

Oertli, J. and Hubner, P. (2010). Railway Noise in Europe a 2010 report on the state of the art. Paris: UIC, p.12.

Poisson, F., Gautier, P. and Letourneaux, F. (n.d.). Notes on Numerical Fluid Mechanics and Multidisciplinary Design Noise and Vibration Mitigation for Rail Transportation Systems. [online] Available at: https://uic.org/cdrom/2008/11_wcrr2008/pdf/S.1.1.4.4.pdf [Accessed 30 Apr. 2018].

Scott, N. (2009). Railway transportation. New York: Nova Science Publishers, p.p.242.

Sheng, X., Zhong, T. and Li, Y. (2017). Vibration and sound radiation of slab high-speed railway tracks subject to a moving harmonic load. Journal of Sound and Vibration, [online] 395, pp.160-186. Available at: https://www.sciencedirect.com/science/article/pii/S0022460X17301189 [Accessed 1 May 2018].

Soeta, Y. and Shimokura, R. (2013). Survey of interior noise characteristics in various types of trains. Applied Acoustics, 74(10), pp.1160-1166.

The railways. (1995). Sheffield: Advanced Railway Research Centre, p.23.

Transport policy and the environment. (1990). Paris: Organisation for Economic Co-operation and Development, pp.120, 131.

Tuler, M. and Kaewunruen, S. (2017). Life cycle analysis of mitigation methodologies for railway rolling noise and groundbourne vibration. Journal of Environmental Management, [online] 191, pp.75-82. Available at: https://www.sciencedirect.com/science/article/pii/S0301479716310684 [Accessed 2 May 2018].

Uic.org. (2018). World High Speed Rolling Stock. [online] Available at: https://uic.org/IMG/pdf/20180401_high_speed_rolling_stock.pdf [Accessed 30 Apr. 2018].

Vos, P. (2016). Railway Noise in Europe-State of the Art Report. [online] Uic.org. Available at: https://uic.org/IMG/pdf/railway_noise_in_europe_2016_final.pdf [Accessed 21 May 2018].

Whitelegg, J. and Haq, G. (2003). World Transport. London: Earthscan Publications Ltd, p.19.

Wolf, S. (2010). California High-Speed Train Project. [online] Hsr.ca.gov. Available at: http://www.hsr.ca.gov/docs/programs/eir_memos/Proj_Guidelines_SoundFactSht.pdf [Accessed 30 Apr. 2018].

Worldometers.info. (2018). Population by Country (2018) - Worldometers. [online] Available at: http://www.worldometers.info/world-population/population-by-country/ [Accessed 30 Apr. 2018].

Zhang, J., Xiao, X., Sheng, X., Zhang, C., Wang, R. and Jin, X. (2016). SEA and contribution analysis for interior noise of a high speed train. Applied Acoustics, [online] 112, pp.158-170. Available at: https://www.sciencedirect.com/science/article/pii/S0003682X16301414 [Accessed 1 May 2018].

Zhang, X. (2010). The directivity of railway noise at different speeds. Journal of Sound and Vibration, [online] 329(25), pp.5273-5288. Available at: https://www.sciencedirect.com/science/article/pii/S0022460X10004384 [Accessed 1 May 2018].

Zhang, X. and Jonasson, H. (2006). Directivity of railway noise sources. Journal of Sound and Vibration, [online] 293(3-5), pp.995-1006. Available at: https://www.sciencedirect.com/science/article/pii /S0022460X05007972 [Accessed 1 May 2018]. 